\title{
Om museologiska utbildningar i Sverige
}

\author{
KERSTIN SMEDS*
}

Museologi är ett ämne som befattar sig med begreppet Förlust i vår kultur, som existentiellt, filosofiskt och praktiskt problem, kopplat till tiden och främst till den materiella verkligheten. Museologin, liksom också museet, ägnar sig åt studium och analys av människans säregna och fåfänga kamp mot nedbrytningen, förgängelsen, förfallet, förruttnelsen, döden. Museologi är en "kulturarvsvetenskap", detta tämligen nya begrepp, som numera täcker också andra "gamla" vetenskaper, eller delar av dem, såsom kulturhistoria, historia, etnologi och arkeologi. Precis som man om historieskrivningen för drygt 100 år sedan frågade sig om det var vetenskap eller konst, och till slut motvilligt erkände den som vetenskap, är det många som idag frågar sig om museologin överhuvudtaget är vetenskap. Och vad skall den vara bra för.

Museologi har, vare sig man vill eller inte, etablerat sig som ett akademiskt ämne, som därtill befinner sig i ständigt växande i samma takt som "kulturarvsbruket" breder ut sig och musealiseringen av världen ökar i rasande takt överallt i världen. I Sverige leder tillkomsten av ständigt nya utbildningar och kurser till att studenterna snart inte räcker till.

Ur teoretisk synvinkel är museologin tämligen svag och bär inte sig själv. Den teoretiska diskussionen har huvudsakligen handlat om att överhuvudtaget definiera ämnet och dess olika infallsvinklar. Museologi utgör en disciplin som likt en spindel väver nät tvärs över och genom ovannämnda discipliners gränser och lånar teorier av andra, som ett slags gökunge i kulturarvsvetenskapernas bo. Museologi är, i motsats till de andra, från födseln tvärvetenskapligt, rentav "metavetenskapligt" i viss, ödmjuk, bemärkelse.

Museologins utveckling ${ }^{1}$ kan följas från 1800talets "lära om museet" - på tyska Museumskunde - om dess praktiska funktioner och verksamhet, till en "museets filosofi" som teoretiskt dryftar museet och musealiseringen som fenomen och ideologi samt vårt förhållande till det materiella arvet i det moderna samhället. Ämnets kunskapsobjekt kan således vara både själva museet som institution, ett praktiskt och empiriskt inriktat ämne, och et ämne som ur sociokulturell synvinkel analyserar museets och de "museala" näringarnas roll och funktion i vårt samhälle.

Jag ger här endast en översiktlig presentation av de museologiska utbildningarna i Sverige idag, utan att så mycket gå in på hur dessa utbildningar sett ut tidigare, och framför allt inte tala om hur de förhåller sig till arbetsmarknaden och karriärmöjligheter - vilket vore en annan, mycket viktig fråga att undersöka närmare. Avsikten är inte att ge en fullständig bild av fältet - det finns säkert en hel del mindre kurser på olika håll i landet som 
jag inte här ägnar någon uppmärksamhet, utan koncentrerar mig på det jag uppfattar som de viktigaste utbildningarna.

\section{UMEÅ UNIVERSITET}

Vi börjar med Umeå universitet, därför att den kom först. Museologin där har sitt ursprung $\mathrm{i}$ en av de Kulturvetarlinjer som instiftades i så gott som samtliga svenska universitet kring decennieskiftet 1980. Dessa linjer var programutbildningar, och profilerade sig på olika sätt vid olika universitet. I Umeå blev det en inriktning på museer och kulturmiljövård, med Västerbottens museums f.d. chef Per-Uno Ågren i spetsen från 1981. I början var det fråga om en två terminers kurs; $A+B$, med fokus på humanekologi och inriktning mot de små museernas problematik. I början av nittiotalet tillkom C-nivån, och mitten av nittiotalet omvandlades hela denna utbildning till en professur i museologi med alla nivåer upp till 160 poäng, magister med museologisk inriktning, jämte forskarutbildning.

Detta är den första professuren i ämnet i Norden, något år senare instiftades en professur i museologi i Jyväskylä i Finland. Dessa två är fortfarande de enda professurerna i ämnet i Norden. År 2001 tillträdde den första ordinarie professorn i Umeå på 20 procent, och från hösten 2003 på 100 procent. Från 1999 har ämnet museologi tillsammans med etnologi och medie- och kommunikationsvetenskap fromt Institutionen för kultur \& medier.

Endast en person har emellertid doktorerat i ämnet i Umeå, och fyra doktorer till lär det skall bli inom en snar framtid. På denna punkt kämpar institutionen för kultur och medier inte bara med ekonomiska problem - det frigörs alltför få eller inga nya doktorandtjänster. Ämnet lider också av ett ännu inte helt vaknat intresse för att doktorera $\mathrm{i}$ just museologi. Detta bottnar i det faktum att de flesta studenter ser utbildningen som en ren yrkesutbildning, som inte har med akademisk forskning att göra. Här finns dessvärre inte utrymme att gå in på just denna problematik, som är nog så intressant.

Museologin i Umeå bygger som sagt på en bred bas. Vi definierar - på samma sätt som man gör framför allt i Östeuropa men också i Frankrike - museologi som en "kulturarvsvetenskap" som täcker inte bara museet, utan hela kulturarvsfältet med allt vad det idag innebär. Hela A-kursen (20 poäng, 1 termin) är därför vikt åt kartläggning av olika slags kulturarv inklusive natur- och industriarv, jämte bevarandeinstitutionernas och -praktikernas historia. B-kursen (20 p) är vikt åt museet och dess samlingar; det "publika museet", med ting, förmedling, semiotik och utställningar i fokus. Denna tonvikt ligger som grund för att hitta synergier med institutionens två övriga ämnen, framför allt medieoch kommunikationsvetenskap. C-kursen (20 p) är mest praktik och uppsats eller projektarbete, och D-nivån (20 p) koncentrerar sig i sin helhet på internationell museologi och teori. Mellan $\mathrm{C}$ och $\mathrm{D}$ ligger tre terminers obligatoriska studier i något annat ämne. Här sker nu med Bolognaprocessen vissa förändringar och påbyggnad på mastersnivån, som kan studeras på vår hemsida www.umu.se/ kultmed/museologi.

Forskarutbildningen i museologi har tidigare varit enbart vikt för studenter som avlagt A,B, C och D i museologi, men har numera öppnat dörrarna också för studenter från andra, närliggande ämnen såsom konstvetenskap, historia, idéhistroia, arkeologi. 
$138 \quad$ UPPSALA

Vid Uppsala universitet fanns också långt innan museologi inrättades som ett ämne, vissa enstaka kurser i "museikunskap". När ämnet år 2000 etablerades på allvar som en 60-poängsutbildning vid institutionen för ABM arkiv, bibliotek, museer - innebar det de påföljande åren att antalet studenter i Umeå gick ner en smula, också beroende på inrättandet av en curatorutbildning vid Stockholms universitet. I motsats till Umeå, där programmet är en hel ämnesutbildning som tar emot också nyexaminerade studenter från gymnasiet, är Uppsala en påbyggnadsutbildning som kräver 60 poäng (3 terminer) andra ämnesstudier som grund. Även i Umeå har man diskuterat fördelen med en påbyggnadsutbildning - nämligen den att studenterna redan besitter en viss mängd kunskap och allmänbildning. Svårigheten med en blandning av nyblivna och mer erfarna studenter är självfallet att hitta rätt nivå på undervisningen - som blir alltför elementär för en del, och kanske för svår för andra.

I Uppsala, även där avvikande från Umeå, koncentrerar sig A och B-kurserna nästan uteslutande på just museet och dess olika funktioner, ofta i samklang med de på samma institution härbärgerade arkiv- och biblioteksutbildningarna. Det handlar bl.a. om samlandets teori och praktik, vetenskaplig klassifikation, dokumentation, administration och kulturarvsdefinitioner. Därtill är genusperspektivet mycket starkt - man kan läsa en 10 poängskurs som heter "Det bekönade museet".

\section{STOCKHOLM}

Vid Stockholms universitet finns ingen utbildning som bär namnet museologi, men ämnet ingår ändå i två livaktiga kurser som administreras av historiska institutionen. Den ena heter "Curatorutbibildning" (20 p) och den andra "Kurs i kulturarv och nya media" (10 p). Förstnämnda inrättades 2001 och den andra 2006. Curatorutbildningen är, såsom namnet antyder, en påbyggnadskurs med förkunskapskrav om 100 poäng, och tyngdpunkten ligger på konstvetenskap och utställningsmediet på detta område. Syftet är, enligt formuleringen i kursplanen, att ge grundläggande kunskaper om utställningsmediet och utställningsproduktion i dagens samhälle. Även kursen i Kulturarv och nya media kan kallas museologisk om man tillämpar begreppet i vidare bemärkelse. Kursens syfte är att studenterna skall förvärva kunskap om nya mediers användbarhet för minneshantering och problematisering av det materiella kulturarvet. I motsats till curatorutbildningen krävs här endast grundläggande behörighet för högskolestudier, det är således inte en påbyggnadsutbildning utan grundkurs.

\section{LUND}

Vid Lunds universitet startades våren 2004 en ny museologisk utbildning på institutionen för Kulturvetenskap, omfattande två kurser, den ena om 20 poäng och den andra 40 poäng. Dessa är emellertid i skrivande stund nedlagda pga omstrukturering med tanke på Bolognaprocessen. Bägge kurser har varit påbyggnadsutbildningar och alltså krävt 80 poäng tidigare akademiska studier. Även dessa har helt riktat in sig på museet som institution och fenomen, inte på kulturarv och historiebruk i bred bemärkelse. Det har handlat om museiväsendets uppkomst och museisektorn i Sverige med internationella utblickar. 
Från höstterminen 2008 skall museologin i Lund ingå $\mathrm{i}$ en ny internationell mastersutbildning (2 år) där arkivvetenskap, biblioteksoch informationsvetenskap samt museologi integreras. Arbetsnamnet är ABM-master (Arkiv, Bibliotek, Museer). Kandidatexamen, av vilken 60 p bör vara valfritt huvudämne, krävs för behörighet till mastersutbildningen.

\section{GÖTEBORG}

Även den tvååriga internationella mastersutbildning - Museion - som administreras av Göteborgs universitet har kommit till på 2000-talet, närmare bestämt 2001 i samarbete med Världskulturmuseet. Utbildningen är ett i Sverige unikt samarbete mellan universitet och museum såtillvida att hela utbildningen fysiskt är placerad på Världskulturmuseet, och sålunda mycket konkret inriktad på museets roll och problem idag, liksom framför allt förmedlingsverksamhet. Inom ramen för utbildningen bedrivs också forskningsverksamhet som är direkt anknuten till museets dagliga verksamhet, inte minst utställningsmediet. Självfallet innebär det här att utbildningen egentligen inte alls tar upp frågor om kulturarvet och kulturarvsbruket i stort.

Undervisningen försiggår på engelska. Ett dylikt intimt samarbete är utan tvivel något som har framtiden för sig, och liknande lösningar finns också på annat håll, bl.a. vid det naturhistoriska riksmuseet Naturalis i Leiden i Holland. I Österrike har vissa framgångsrika museologiska kurser helt sonika flyttats, också administrativt, från universitetet $\mathrm{i}$ Wien till ett stort museikonglomerat i Graz, kallat Museum Joanneum. Där handlar det om ren fortbildning, framför allt med fokus på kompetensutveckling för museipersonal. Även till Göte- borg söker sig en hel del museianställda från 139 olika delar av världen, som ett led i kompetensutveckling i branschen. Med denna masters i bagaget kan man också söka sig till doktorandutbildningar i museologi, t.ex. till Umeå.

\section{LINKÖPING/NORRKÖPING}

Ett par små utbildningar till bör nämnas, framför allt den framgångsrika lilla kursen (10 p) i utställningsgestaltning vid Institutionen för Kultur, samhälle och media (KSM / ISAK) vid Linköpings universitet, campus Norrköping. Kursen, som har en estetisk inriktning, är riktad främst mot redan yrkesaktiva "utställningsgestaltare” och producenter, inte minst konstnärer och scenografer.

\section{KALMAR OCH VÄXJÖ}

Till sist kan nämnas en utbildning vid Kalmar Högskola, kallad "Kulturarv och samhällsanalys" (180 p) och en i vid Växjö universitet som heter "Historiebruk och historieförmedling" (40 p). Bägge kan kanske klassificeras som "museologiska" om man tar till den bredaste definitionen av ämnet. Förstnämnda är intressant för att flere ämnen där har slagit ihop sina påsar över ämnesgränserna och definierat något nytt. Utbildningen siktar på filosofie kandidat- eller magisterexamen $\mathrm{i}$ antingen arkeologi, historia, kulturgeografi eller sociologi. Endast det första året är gemensamt, och ger en bas för kulturarvssektorn i stort. Därefter väljer man ett av ovannämnda ämnen. "Historiebruk och historieförmedling” i Växjö är en påbyggnadsutbildning som leder till en magisterexamen med inriktning mot historieförmedling. Programmet riktar sig särskilt till yr- 
140 kesgrupper inom kulturarvssektorn, turistnäringen och utbildningsväsendet.

\section{SAMMANFATTNING}

Med denna lilla genomgång kan man konstatera att:

- med undantag av Umeå och Uppsala, de museologiskt inriktade utbildningarna i Sverige är tämligen nya, instiftade på 2000-talet.

- Umeå är den enda som omfattar 16/180 poäng studier $i$ ämnet, och där ingår tre terminer andra humanistiska ämnesstudier i utbildningsprogrammet (mellan C och D-nivån).

- Alla övriga är påbyggnadsutbildningar, vilket i och för sig är naturligt på ett så pass mångfacetterat och komplicerat område som detta.

- Umeå är också den enda som har en tämligen brett definierad bas, som omfattar hela kulturarvsområdet, inte bara museet. De övriga, med undantag av de speciella utbildningarna i Norrköping, Kalmar och Växjö, har fokus på själva museet som institution och dess funktioner och roller. I Uppsala liksom i den kommande masters i Lund, är utbildningen tätt sammankopplad till arkivoch bibliotekssektorn.

- Umeå och Museion i Göteborg är de enda som initierar egen forskning på området, i Umeås fall omfattande också doktorandstudier, i Göteborg endast post doc-forskning. Det här betyder ingalunda att det inte skulle försiggå massor av "museologisk" forskning i landet inom övriga humanistiska ämnen, såsom konstvetenskap, arkeologi, historia, idéhistoria, sociologi, t.o.m. arkitektur.

\section{NOTER}

1. Översiktsverk, se tex två nya: André Gob \& Noémie Drouget: La musologie. Histoire, développements, enjeux actuels. Paris 2003; Hildegard Vieregg: Museumswissenschaften. Eine Einfübrung. 2006; eller den något äldre boken Ivo Maroevic Introduction to museology: the European approach. English ed. / rev. and ed. by Gary Edson. Munich: Müller-Straten 1998.

2. Bernard Déloche, "Muséologie et philosophie": ICOM International Council of Museums, ICOFOM, Comité international pour la muséologie: Museology and Philosophy. Muséologie et philosophie etc... Ed. By Hildegard Vieregg, ICOFOM STUDY SERIES- ISS 31, Coro, Venezuela, November 28 - December 04, 1999. Museums-Pädagogisches Zentrum, München 1999.

*Kerstin Smeds, professor i museologi, Umeå universitet, Sverige.

E-mail:kerstin.smeds@kultmed.umu.se 